Asian J Agric \& Biol. 2021(1).

\title{
Impact of abiotic factors on the foraging behavior of two honeybee species on canola in Bahawalpur, Punjab-Pakistan
}

\author{
Muhammad Aslam Farooqi1 ${ }^{1}$, Muhammad Naveed Aslam² ${ }^{*}$, Asif Sajjad1 ${ }^{1}$, Waseem Akram¹, Aneeqa Maqsood ${ }^{3}$ \\ ${ }^{1}$ Department of Entomology, Faculty of Agriculture and Environmental Sciences, The Islamia University of Bahawalpur, \\ Pakistan \\ ${ }^{2}$ Department of Plant Pathology, Faculty of Agriculture and Environmental Sciences, The Islamia University of Bahawalpur, \\ Pakistan \\ ${ }^{3}$ Department of Entomology, Bahauddin Zakariya University, Multan, Pakistan
}

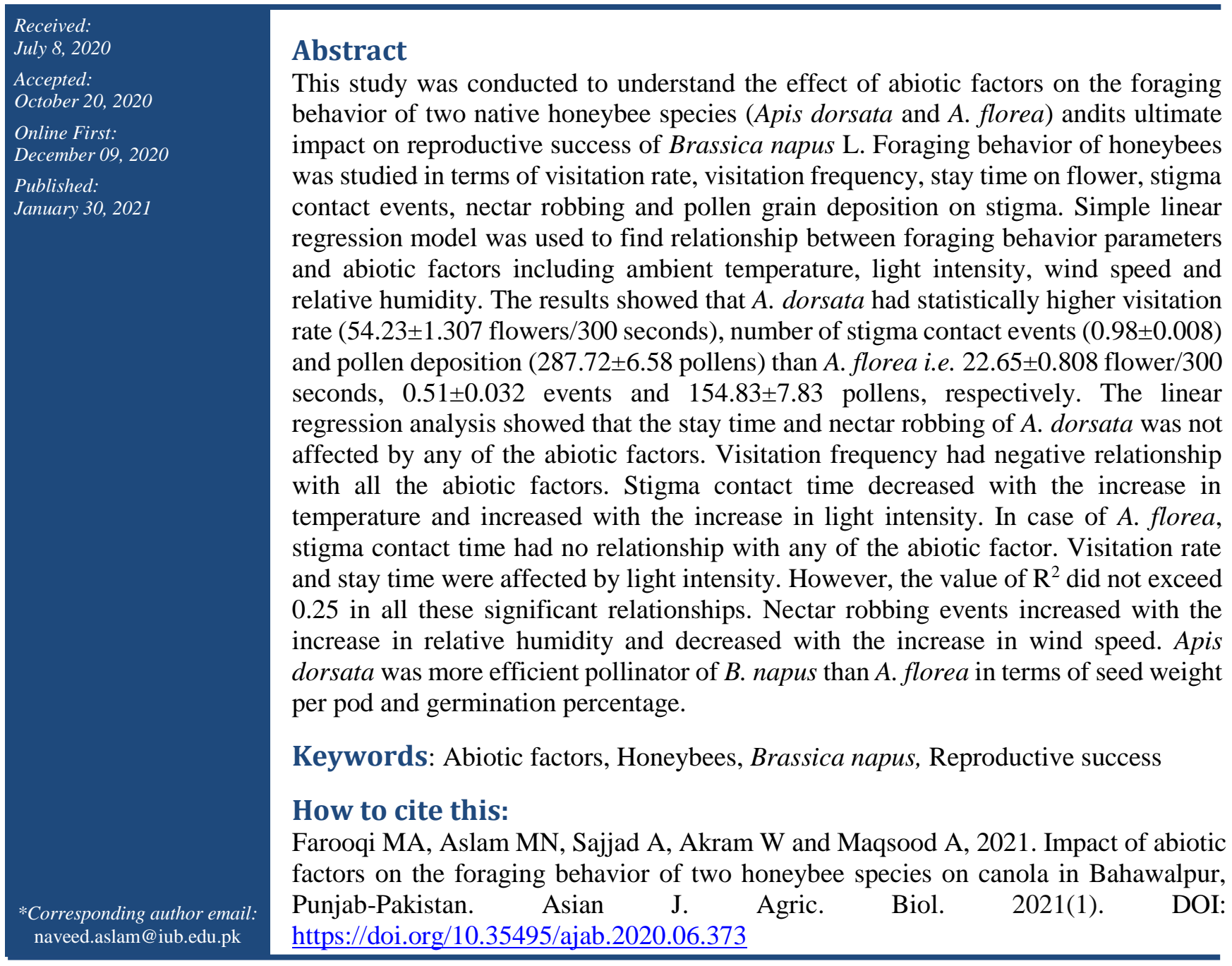

This is an Open Access article distributed under the terms of the Creative Commons Attribution 3.0 License. (https://creativecommons.org/licenses/by/3.0), which permits unrestricted use, distribution, and reproduction in any medium, provided the original work is properly cited. 


\section{Introduction}

Insect species belonging to the order Hymenoptera are affected by a number of abiotic factors such as rainfall, humidity, temperature, wind velocity and light radiation (Southwick and Moritz, 1987). For example, in case of bees and wasps, the most important abiotic factor is ambient air temperature (Heinrich, 1984). Insect pollinators respond very rapidly to the external temperature as they are endothermic in nature. Variation in temperature and rainfall strongly predicts their relationship with host plants (Hilário et al., 2000). Besides this, temperature also affects the survival, fecundity, development, population size and migration of several insect species ( Régnière et al., 2012).

The flying activity of most of the insect species is directly proportional to temperature up to a certain optimum limit and beyond that, it is inversely proportional (Taylor, 1963). Both the density dependent and independent factors determine different life history traits of insects like geographical distribution, relative abundance, growth rate, overwintering, interspecific competition, number of generations (Savopoulou-Soultani et al., 2012) and population dynamics (Shivanna et al., 2011). The foraging and defensive behavior of honeybees is strongly affected by certain density independent factors i.e., temperature, wind speed, light, rainfall and humidity. Recent studies have provided the optimum ranges of abiotic factors for honeybee activities along with corresponding impacts of high or low levels of these factors (Southwick and Moritz, 1987).

Pollination is an important ecosystem service delivered by insects responsible for production of twothirds of the crop plants (Ricketts, 2004). From total consumption of the world food, $90 \%$ is being pollinated from the activities of honey bees and almost from 100 valuable crops of the world, $70 \%$ are being pollinated by honeybees (Moritz et al., 2005; Klein et al., 2007). In Pakistan, Brassica napus (canola) ranks third after sunflower and cotton contributing $17 \%$ of the total domestic edible oil; grown on an area of nearly 0.402 million acres (GOP, 2009). Its flowers are entomophilous in nature capable of both self and cross-pollination. The out-crossing rate ranges from 12 to $47 \%$ depending on cultivar (Williams et al., 1986; Becker et al., 1992). The cross-pollination by insects can increases the seed weight of $B$. napus by $18 \%$ and its market value by $20 \%$ (Bommarco et al., 2012). Honeybees have been recognized as the most common visitor of $B$. napus flowers. The shallow settlement of its visible nectar and yellow color mostly attracts bees, flies and butterflies (Kunin, 1993).

Insect pollinators, especially the bees, ensure the successful reproduction of plants through crosspollination (Lane and David, 2006). However, foraging activities (i.e. foraging behavior) of bees are strongly influenced by unpredictable environmental variables (Tripath, 2011; Tirado et al., 2013) and timing and location of food (Biesmeijer and Ermers, 1999). All the daily foraging activities and foraging patterns of honeybees sharply change with weather conditions. Bees therefore can accordingly alter their floral resource preferences depending on temperature, rainfall, wind, relative humidity and sunshine. However, each social bee species has its own set of microclimate in which its foraging activity can be sustained (Contreras et al., 2013). Conserving and utilization of alternate native pollinators, especially the bees therefore appear to be a right choice for successful B. napus production (Sajjad et al., 2008). To understand whether a particular honeybee species could be an effective pollinator in a given climate, it is imperative to understand its foraging behavior in response to the local climatic factors. The current study was carried out to evaluate the impact of density independent factors on foraging behavior of two native honey bee species, A. dorsata and A. florea and its ultimate impact on reproductive success of B. napus.

\section{Material and Methods}

\section{Research and study area}

Canola, Brassica napus L. was sown during first week of November 2018 at the research farm of Regional Agriculture Research Institute (RARI) Bahawalpur, Punjab, Pakistan. Blooming and our systematic observations were from $1^{\text {st }}$ February to $15^{\text {th }}$ April. The climate of this region is sub-tropical with mean daily minimum and maximum temperature range of $15^{\circ} \mathrm{C}$ to $25^{\circ} \mathrm{C}$ and $30^{\circ} \mathrm{C}$ to $35^{\circ} \mathrm{C}$, respectively. The average annual rainfall is about 300 to $500 \mathrm{~mm}$ (Khan et al., 2010). The area is about 181 meter above sea level. We selected an area of 2 acres for experimentation during the peak flowering period of B. napus.

\section{Foraging behavior of honeybees}

Different parameters of foraging behavior of $A$. dorsata and A. florea were recorded i.e., visitation frequency, visitation rate, stay time per flower, stigma contact time and side feeding (nectar robbing). Visitation rate is defined as number of flowers visited 
in a unit time (i.e., five minutes in this study). Visitation frequency is defined as number of bees visited on a specific plant in a unit time (i.e., five minutes in this study). Stay time is the duration of stay on a flower in a single visit. Sometime pollinators tend to feed on nectar without coming in contact with stigma is called nectar robbing e.g. side feeding by honeybees.

\section{Visitation rate}

To record visitation rate of a bee species at five different times of a day (i.e., 10:00 hrs, 12:00 hrs, 14:00 hrs, 16:00 hrs and 17:00 hrs), we randomly selected ten plants and counted the number of flowers visited by $A$. dorsata and A. florea in five minutes. A stop watch was used for recording five minutes of observations. In this way there was a total of 50 minutes of observation in a day and we repeated taking such observations four times in a season i.e. usually with the interval of seven days. Before recording visitation rates, the temperature and relative humidity was recorded with the help of a field thermohygrometer, light intensity with the help of a lux meter and wind speed with the help of an anemometer.

\section{Visitation frequency}

To record visitation frequency of honeybees at five different time intervals of a day (i.e., 10:00 hrs, 12:00 hrs, 14:00 hrs, 16:00 hrs and 17:00 hrs) 10 plants were randomly selected and each plant was observed for five minutes to record the number of individuals of each bee species, visiting on the flowers. Stop watch was used for this purpose. A total of 250 minutes of observation in a day was recorded four times in the season usually with the interval of seven days.

\section{Stay time}

The stay time of both the honeybee species was recorded on 10:00 hrs, 12:00 hrs, 14:00 hrs, $1600 \mathrm{hrs}$ and $1700 \mathrm{hrs}$ in a day. At each interval, twenty individuals of each bee species were observed for the time spent on a single flower. A stopwatch was used for this purpose. This procedure was repeated four times in a season usually with the interval of seven days. Weather conditions were always recorded before systematic observations.

\section{Nectar robbing and stigma contact duration}

We determined nectar robbing events (side feeding without coming in contact with stigma) and stigma contact duration in both the honeybee species at different time intervals of a day i.e., 10:00 hrs, 12:00, 14:00 hrs, $1600 \mathrm{hrs}$ and $1700 \mathrm{hrs}$. A stopwatch was used to measure the length of time an individual bee remained in contact with the stigma during a single visit.

\section{Role of honeybees in pollination}

The single visit efficiency of $A$. dorsata and A. florea was recorded in two different ways i.e. in terms of pollen deposition on stigma and in terms of plant reproductive success. In case of single visit efficiency, we caged 40 floral buds of $B$. napus (20 for each bee species) with nylon mesh bags 24 hours before their opening. The flowers were unveiled during the peak activity timing (10:00 hrs to 14:00 hrs) of pollinators. Once a flower had been visited by the honeybee species, the stigma was excised and dipped into a drop of ethyl alcohol placed on glass slide. Subsequently, a cover slip was placed on it and number of pollen grains were counted under 40X stereo-microscope (Akram et al., 2019).

Similarly, in case of plant reproductive success, we caged 40 floral buds of B. napus (20 for each bee species) with nylon mesh bags 24 hours before their opening. The flowers were unveiled during the peak activity timing (10:00 hrs to 14:00 hrs) of pollinators. Once the flowers had been visited by the honeybee species, the flowers were re-caged and tagged. The nylon mesh bags were removed once pods had been formed. Upon the maturity, the pods were removed and measured for pod length, pod weight, number of seeds per pod, seed weight per pod and germination percentage. We also maintained 20 floral buds which were caged throughout flower opening period and regarded it as self-pollinated while maintained 20 other floral buds which were kept open (without cage) and regarded as cross-pollinated.

\section{Data analysis}

T-test was used to compare the means of two independent samples of $A$. dorsata and A. florea in terms of their visitation rate, visitation frequency, stay time, stigma contact time, stigma contact events, stigma contact duration, nectar robbing events and pollen deposition. Simple linear regression analysis was applied to see relationship between foraging behaviors (visitation rate, stay time, visitation frequency, stigma contact duration and nectar robbing) and abiotic factors (ambient temperature, relative humidity, light intensity and wind speed). In order to compare reproductive performance of $A$. dorsata and 
A. florea along with self-pollinated and crosspollinated flowers, one way ANOVA was applied on reproductive success parameters. The means were compared by Tukey's post hoc test at alpha 0.05 . Pearson's correlation coefficient was also used to see the relationship between different reproductive success parameters.

\section{Results}

Results of T-test showed that A. dorsata and A. florea were statistically significantly different in terms of visitation rate, visitation frequency, stay time, stigma contact duration, stigma contact events, nectar robbing and pollen deposition. Visitation rate, stigma contact events and pollen deposition were highest in $A$. dorsata whereas visitation frequency, stay time, stigma contact duration and nectar robbing were highest in A. florea (Table 1).

The linear regression analysis showed that the visitation rate of both $A$. dorsata and A. florea were significantly affected by wind speed, temperature and light intensity. Wind speed was negatively related with visitation rate in case of $A$. dorsata while it was positively related in case of $A$. florea. Temperature and light intensity were positively related with visitation rate of both $A$. dorsata and A. florea. Relative humidity, however, had no relationship with visitation rate of both the species (Table $2 \& 3$ ).Abiotic factors depicted the visitation frequency of $A$. dorsata better than A. florea. In case of A. florea wind speed, relative humidity and temperature had no relationship with visitation frequency. On the other hand, they were negatively related with visitation frequency of $A$. dorsata. Contrary to A. dorsata, light intensity had a positive relationship with visitation frequency of $A$. florea.

All the four abiotic factors failed to predict stay time of $A$. dorsata while temperature and light intensity had a strong negative relationship with stay time of $A$. florea. Stigma contact time of A. florea largely remained unaffected by abiotic factors as there was a significant relationship between abiotic factors with stay time. In case of $A$. dorsata, temperature had a strong negative while light intensity had a strong positive relationship with stay time. Apis dorsata rarely robbed the nectar in this study. However, weather factors did not affect the nectar robbing in $A$. dorsata. On the other hand, wind speed significantly reduced the nectar robbing while relative humidity significantly increased it in A. florea (Table $2 \& 3$ ). However, the value of $\mathrm{R}^{2}$ did not exceed 0.25 in all these significant relationships.

There were statistically significant differences among pod weight, pod length, number of seeds per pod, weight of seeds per pod and germination percentage. The maximum pod weight was recorded in A. dorsata $(0.51 \mathrm{~g})$ followed by A. florea $(0.50 \mathrm{~g})$, open $(0.12 \mathrm{~g})$ and caged $(0.09 \mathrm{~g})$. The maximum pod length was recorded in A. dorsata $(7.16 \mathrm{~cm})$ followed by $A$. florea $(7.03 \mathrm{~cm})$, open $(6.64 \mathrm{~cm})$ and caged $(4.13 \mathrm{~cm})$. The highest number of seeds per pod was recorded in $A$. dorsata (28.55) followed by A. florea (27.60), open (16.89) and caged (8.50). The maximum seed weight per pod was recorded in A. dorsata $(0.12 \mathrm{~g})$ followed by $A$. florea $(0.10 \mathrm{~g})$, open $(0.06 \mathrm{~g})$ and caged $(0.05 \mathrm{~g})$. Apis dorsata pollinated seeds were highest in germination percentage whereas minimum germination percentage was recorded in A. florea pollinated seeds (Table 4).

The Pearson's correlation matrix among different reproductive success parameters of canola crop as a result of different pollination treatment i.e. A. dorsata, A. florea, open and caged is shown in Table (5). Except germination, all the reproduction parameters had a strong significant positive relationship among each other.

Table-1. Comparison of means of different foraging behaviors of Apis dorsata and Apis florea using t-test of independent sample comparison

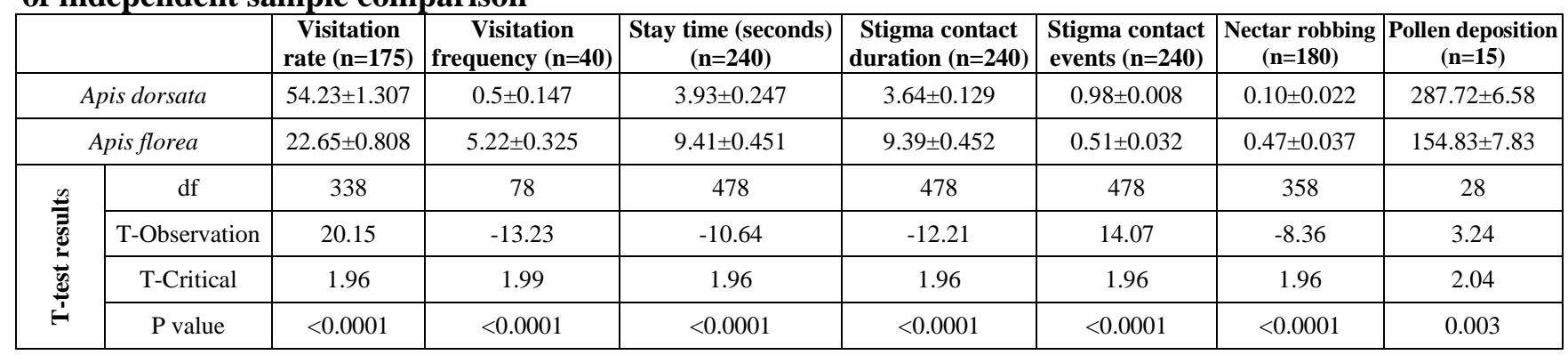


Muhammad Aslam Farooqi et al.

Table-2. Relationship between different foraging behavior parameters of Apis dorsata and abiotic factors using linear regression analysis

\begin{tabular}{|c|c|c|c|c|}
\hline Linear Model & $\mathbf{R}^{2}$ & $\mathbf{F}$ & $\mathbf{P}$ & $\mathbf{N}$ \\
\hline Visitation rate $=61.92-1.44 \times$ Wind speed & 0.055 & 9.745 & 0.002 & 171 \\
\hline Visitation rate $=43.10+0.24 \times$ Relative humidity & 0.019 & 3.207 & 0.075 & 171 \\
\hline Visitation rate $=14.22+1.56 \times$ Temperature & 0.129 & 25.060 & $<0.0001$ & 171 \\
\hline Visitation rate $=36.35+2.83 \times$ Light intensity & 0.076 & 13.838 & 0.000 & 171 \\
\hline Visiting frequency $=11.51-1.08 \mathrm{x}$ Wind speed & 0.103 & 18.923 & $<0.0001$ & 166 \\
\hline visiting frequency $=15.67-0.20 \times$ Relative Humidity & 0.030 & 5.010 & 0.027 & 166 \\
\hline visiting frequency $=42.50-1.38 \times$ Temperature & 0.255 & 56.158 & $<0.0001$ & 166 \\
\hline visitation frequency $=23.45-2.34 \mathrm{x}$ Light intensity & 0.063 & 10.962 & 0.001 & 166 \\
\hline Stay time $=3.87+1.39 \times$ Wind speed & 0.000 & 0.025 & 0.874 & 240 \\
\hline Stay time $=5.27-2.84 \times$ Relative humidity & 0.002 & 0.586 & 0.445 & 240 \\
\hline Stay time $=6.25-9.06 \times$ Temperature & 0.008 & 1.902 & 0.169 & 240 \\
\hline Stay time $=9.16-7.07 \mathrm{x}$ Light intensity & 0.012 & 2.830 & 0.094 & 240 \\
\hline Stigma contact duration $=0.67-4.05 \times$ Wind speed & 0.009 & 2.182 & 0.141 & 240 \\
\hline Stigma contact duration $=8.66-1.48 \times$ Relative humidity & 0.006 & 1.352 & 0.246 & 240 \\
\hline Stigma contact duration $=0.15-5.33 \times$ Temperature & 0,024 & 5.945 & 0.015 & 240 \\
\hline Stigma contact duration $=0.64+4.61 \mathrm{x}$ Light intensity & 0.044 & 11.076 & 0.001 & 240 \\
\hline Nectar robbing $=6.19+8.95 \times$ Wind speed & 0.006 & 1.117 & 0.292 & 180 \\
\hline Nectar robbing $=-1.76+2.61 \times$ Relative humidity & 0.003 & 0.541 & 0.463 & 180 \\
\hline Nectar robbing $=0.14-1.38 \times$ Temperature & 0.000 & 0.051 & 0.822 & 180 \\
\hline Nectar robbing $=6.19+6.01 \times$ Light intensity & 0.000 & 0.022 & 0.882 & 180 \\
\hline
\end{tabular}

Table-3. Relationship between different foraging behavior parameters of Apis florea and abiotic factors using linear regression analysis

\begin{tabular}{|c|c|c|c|c|}
\hline Linear Model & $\mathbf{R}^{2}$ & $\mathbf{F}$ & $\mathbf{P}$ & $\mathbf{N}$ \\
\hline Visitation rate $=14.88+1.31 \times$ Wind speed & 0.100 & 18.847 & $<0.0001$ & 171 \\
\hline Visitation rate $=26.06-9.49 \times$ Relative humidity & 0.006 & 1.089 & 0.298 & 171 \\
\hline Visitation rate $=-1.26+0.88 \times$ Temperature & 0.093 & 17.349 & $<0.0001$ & 171 \\
\hline Visitation rate $=0.83+3.23 \times$ Light intensity & 0.221 & 47.978 & $<0.0001$ & 171 \\
\hline Visiting frequency $=6.96-1.49 \mathrm{x}$ Wind speed & 0.000 & 0.009 & 0.926 & 166 \\
\hline Visiting frequency $=3.50+7.96 \times$ Relative Humidity & 0.012 & 1.936 & 0.166 & 166 \\
\hline Visiting frequency $=0.75+0.23 \times$ Temperature & 0.020 & 3.377 & 0.068 & 166 \\
\hline Visitation frequency $=-3.09+1.40 \times$ Light intensity & 0.060 & 10.550 & 0.001 & 166 \\
\hline Stay time $=9.87-9.73 \times$ Wind speed & 0.002 & 0.365 & 0.546 & 240 \\
\hline Stay time $=4.85+9.73 \times$ Relative humidity & 0.009 & 2.074 & 0.151 & 240 \\
\hline Stay time $=20.02-0.41 \times$ Temperature & 0.050 & 12.548 & 0.000 & 240 \\
\hline Stay time $=29.21-2.68 \times$ Light intensity & 0.051 & 12.693 & 0.000 & 240 \\
\hline Stigma contact duration $=0.47+7.90 \times$ Wind speed & 0.002 & 0.439 & 0.508 & 240 \\
\hline Stigma contact duration $=0.28+5.004 \times$ Relative humidity & 0.004 & 1.015 & 0.315 & 240 \\
\hline Stigma contact duration $=0.76-9.83 \times$ Temperature & 0.005 & 1.308 & 0.254 & 240 \\
\hline Stigma contact duration $=0.67-2.11 \mathrm{x}$ Light intensity & 0.001 & 0.147 & 0.702 & 240 \\
\hline Nectar robbing $=0.67-4.04 \times$ Wind speed & 0.048 & 9.022 & 0.003 & 180 \\
\hline Nectar robbing $=-0.33+1.71 \times$ Relative humidity & 0.005 & 9.321 & 0.003 & 180 \\
\hline Nectar robbing $=0.29+6.90 \times$ Temperature & 0.003 & 0.481 & 0.489 & 180 \\
\hline Nectar robbing $=0.19+3.87 \times$ Light intensity & 0.002 & 0.351 & 0.554 & 180 \\
\hline
\end{tabular}




\section{Discussion}

Apis dorsata in present study showed significantly higher visitation rate, stigma contact events and pollen deposition in a single visit than A. florea. On the other hand, A. dorsata was inferior to A. florea in terms of visitation frequency, stay time and stigma contact duration. The information on quantitative components of the pollinator visitation (i.e. visitation rate and frequency) together with the knowledge of pollination effectiveness could allow for identification of the potential pollinators of particular crop species (Albano et al., 2009).

Some previous studies confirm the significantly higher visitation rate of $A$. dorsata as compared to A. florea in B. napus (Ali et al., 2011), onion (Sajjad et al., 2008) and pumpkin (Ali et al., 2016). Contrary to this, Zameer et al. (2017) found significantly lower visitation rate of $A$. dorsata than $A$. florea in radish whereas Saeed et al. (2012) did not find any significant difference between visitation rates of two honeybees in bitter gourd. On the other hand, we found higher visitation frequency of $A$. florea as compared to $A$. dorsata in the present study. Contrary to our finding, Ali et al. (2011) observed higher visitation frequency of A. dorsata than A. florea in canola whereas Saeed et al. (2012) observed higher visitation frequency of $A$. florea than A. dorsata in bitter gourd crop.

Table-4. Comparison of pollination effectiveness of honeybees in terms of reproductive performance of Brassica napus

\begin{tabular}{|c|c|c|c|c|c|c|}
\hline \multicolumn{2}{|c|}{ Treatments } & $\begin{array}{c}\begin{array}{c}\text { No. of } \\
\text { seed per } \\
\text { pod }\end{array} \\
\end{array}$ & $\begin{array}{c}\text { Seed } \\
\text { weight/pod } \\
\text { (grams) }\end{array}$ & $\begin{array}{l}\text { Pod } \\
\text { length } \\
\text { (cm) }\end{array}$ & $\begin{array}{c}\begin{array}{c}\text { Pod } \\
\text { weight } \\
\text { (grams) }\end{array} \\
\end{array}$ & $\begin{array}{c}\text { Germina } \\
\text { tion } \\
\text { (\%age) }\end{array}$ \\
\hline \multicolumn{2}{|c|}{ Apis dorsata } & $28.55 \mathrm{a}$ & $0.12 \mathrm{a}$ & $07.16 \mathrm{a}$ & $0.51 \mathrm{a}$ & $98 \mathrm{a}$ \\
\hline \multicolumn{2}{|c|}{ Apis florea } & $27.60 \mathrm{a}$ & $0.10 \mathrm{~b}$ & $07.03 \mathrm{a}$ & $0.50 \mathrm{a}$ & $92 \mathrm{c}$ \\
\hline \multicolumn{2}{|c|}{$\begin{array}{l}\text { Open (cross- } \\
\text { pollinated) }\end{array}$} & $16.80 \mathrm{~b}$ & $0.06 \mathrm{c}$ & $06.64 \mathrm{a}$ & $0.12 \mathrm{~b}$ & $96.10 \mathrm{ab}$ \\
\hline \multicolumn{2}{|c|}{$\begin{array}{l}\text { Caged (self- } \\
\text { pollinated) }\end{array}$} & $08.50 \mathrm{c}$ & $0.05 \mathrm{~d}$ & $04.13 \mathrm{~b}$ & $0.09 \mathrm{~b}$ & $95.20 \mathrm{~b}$ \\
\hline \multirow{3}{*}{ 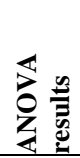 } & df & 3 & 3 & 3 & 3 & 3 \\
\hline & $P$ value & $<0.0001$ & $<0.0001$ & $<0.0001$ & $<0.0001$ & $<0.0001$ \\
\hline & F value & 36.08 & 68.71 & 44.41 & 96.39 & 14.62 \\
\hline
\end{tabular}

*means sharing similar lettering are statistically nonsignificant at alpha 0.05

A number of biotic and abiotic factors could affect the foraging behavior of a particular pollinator species. Sánchez-Lafuente et al. (2005) and Grindeland et al. (2005) reported floral display as mainly responsible for among-plant differences in visitation rates. On the other hand, Albano et al. (2009) concluded that visitation frequency of a particular pollinator species varies considerably across regions, fields and years and therefore the results obtained in such studies should not be directly validated to other cases.

Bee species which are intensive foragers (having high foraging rates) usually work on rapid pace but stay for a shorter period of time on flowers than species with less foraging rates (Sajjad et al., 2008; Ali et al., 2011; Ali et al., 2014; Ali et al., 2016; Zameer et al., 2017). This was also obvious in our study as $A$. dorsata had much higher visitation rate than $A$. florea and showed much lower stay time on flowers than A. florea. Apis florea showed significantly higher nectar robbing events than A. dorsata. Contrary to this, Villalobos and Shelly (1996) found that nectar robbing A. florea had lower visitation rate but higher stay time than $A$. dorsata. In the flowers of canola, the availability of pollen and nectar decreases mostly at 12:00 pm (Meyerhoff, 1954) this may explain why the A. florea robbed nectar.

In the present study, pollen deposition on stigma during a single visit was significantly higher in $A$. dorsata than $A$. florea. The visitation frequency and visitation rate are the most important factors when comparing the pollination efficiency. In general, the greater the visitation frequency and visitation rate, the higher chances of pollination (Singh et al., 2006).Pollen load and pollen harvesting also matters in pollination effectiveness (Canto-Aguilar and ParraTabla, 2000). Several studies have documented bees as vital pollinators based on their ability to deposit more pollen on stigma than flies and butterflies (Ali et al., 2011; Willmer et al., 2017; Zameer et al., 2017). However, some recent accounts have argued that pollen deposition is not always a reliable measure of pollinators' effectiveness. Wang et al. (2017) noticed that pollen deposition was generally inconsistent with reproductive success parameters of plants i.e., seed production. They did not find any correlations between pollen deposition and seed production as a result of single visits made by bees.

In our study, the visitation frequency of $A$. dorsata was negatively associated with wind speed, relative humidity, temperature and light intensity whereas in case of A. florea it was positively related with light intensity and only positively related with temperature and relative humidity. Similar findings were reported from India by Abrol (2010) who noticed that A. florea had significantly positive correlation with air 
temperature, light intensity, solar radiation and negatively with relative humidity.

Table-5. Relationship between reproductive success parameters of canola using Pearson's correlation at alpha 0.05

\begin{tabular}{|c|c|c|c|c|}
\hline & No of seeds & Seed weight & Pod length & Pod weight \\
\hline Seed weight & $0.720^{*}$ & & & \\
\hline Pod length & $0.720^{*}$ & $0.619^{*}$ & & \\
\hline Pod weight & $0.720^{*}$ & $0.671^{*}$ & $0.512^{*}$ & \\
\hline Germination & 0.720 & 0.025 & 0.002 & 0.033 \\
\hline
\end{tabular}

*correlation significant at alpha 0.05

In case of $A$. dorsata, stay time in this study was not affected by any of the weather factor while it was negatively related with temperature and light intensity. However, Stabentheiner and Kovac (2014) reported that duration of stay of honeybees, decreases with ambient air temperature and increases with body temperature. Moreover, foraging in the sun-light enables the foragers to reduce the energetic costs per stay by about $19 \%$ to $76 \%$. Nectar robbing in A. florea increased with relative humidity and decreased with wind speed. Previously no such relationship has been established between potential nectar robbers and environmental factors.

Apis dorsata proved to be a better pollinator than $A$. florea in terms of seed weight per pod and germination percentage. Number of seeds per pod, pod length and pod weight were statistically similar for both the bees. Similar findings were obtained by Ali et al. (2011) and they also found similar correlation among yield attributing components as we obtained in this study. In the present study, the reproductive performance of canola -number of seeds per pod, seed weight per pod and pod weight- was better in single visits than multiple visits (open-pollinated flowers). This is might be due to pollination limitations associated with quantity (number) and quality of pollen grains (Aizen and Harder, 2007). Usually the seed set increases with the number of pollen grains deposited on the stigma up to certain limit and attains an asymptote after certain number of pollen grains (Sorensen and Webber, 1997). Therefore number of pollen grains deposited on stigma is not merely the indicator of good seed set. Moreover, viability of pollen grains and number of heterospecific pollen grains also affect seed set in angiosperms (Bellusci et al., 2010). The behavior of pollen and/or nectar feeding is also important in this regard. In Brassica compestris, single visits of pollen and pollen/nectar feeding pollinator were enough in achieving the maximum seed set. On the other hand, all the single visits of nectar feeding bees resulted in no seed set (Sihag, 2018).

\section{Conclusion}

Apis dorsata had higher visitation rate, number of stigma contact events, pollen deposition, number of seeds per pod and germination percentage as compared to A. florea. Abiotic factors i.e. ambient temperature, relative humidity, wind velocity and light intensity strongly affect the foraging behavior of both A. dorsata and A. florea.

Disclaimer: None.

Conflict of Interest: None.

Source of Funding: This research was financed by Agriculture Linkage Program (ALP) of Pakistan Agriculture Research Council (PARC) under project "Conservation of native bees through ecosystem approach for enhanced crop pollination”.

\section{References}

Abrol DP, 2010. Foraging behaviour of Apis florea F., an important pollinator of Allium cepa L. J. Apic. Res. 49:318-325.

Akram W, Sajjad A, Ali S, Farooqi MA, Mujtaba G, Ali M and Ahmad A, 2019. Pollination of Grewia asiatica (Malvaceae) by Megachile cephalotes (Hymenoptera: Megachilidae) Male vs. Female pollination. Sociobiology 66(3): 467-474.

Albano S, Salvado E, Borges PAV and Mexia A, 2009. Floral visitors, their frequency, activity rate and Index of Visitation Rate in the strawberry fields of Ribatejo, Portugal: selection of potential pollinators. Part 1. Adv. Hort. Sci. 23: 238-245.

Ali M, Saeed S, Sajjad A and Whittington A, 2011 In search of the best native pollinators for canola (Brassica napus L.) production in Punjab, Pakistan. Appl. Entomol. Zool. 46: 353-361.

Ali M, Saeed S and Sajjad A, 2016. Pollen deposition is more important than species richness for seed set in Luffa Gourd. Neotrop. Entomol. 45:499506.

Ali M, Saeed S, Sajjad A and Bashir MA, 2014.Exploring the Best Native Pollinators for Pumpkin (Cucurbita pepo) production in Punjab, Pakistan. Pak. J. Zool. 46: 531-539. 
Aizen MA and Harder LD, 2007. Expanding the limits of the pollen-limitation concept: effects of pollen quantity and quality. Ecology. 88(2): 271-281.

Becker HC, Karle R and Han SS, 1992. Environmental variation for outcrossing rates in rapeseed (Brassica napus). Theor. Appl. Genet. 84: 303306.

Bellusci F, Musacchio A, Stabile R and Pellegrino G, 2010. Differences in pollen viability in relation to different deceptive pollination strategies in Mediterranean orchids. Ann. Bot. 106(5): 769774.

Biesmeijer JC and Ermers MCW, 1999. Social foraging in stingless bees: how colonies of Meliponafasciata choose among nectar sources, Behav. Ecol. Sociobiol. 46: 129-140.

Bommarco R, Marini L and Vaissière BE, 2012. Insect pollination enhances seed yield, quality, and market value in oilseed rape. Oecologia 169: 1025-1032.

Canto-Aguilar MA and Parra-Tabla V, 2000. Importance of conserving alternate pollinators: assessing the pollinator efficiency of the squash bee, Peponapis limitaris in Cucurbita moschata (Cucurbitaceae). J. Insect Conserv. 4:203-210.

Contreras HL, Goyret J, Arx MV, Pierce CT, Bronstein JL, Raguso RA and Davidowitz G, 2013. The effect of ambient humidity on the foraging behavior of the hawkmoth Manduca sexta. J. Comp. Physiol. 199:1053-1063.

Government of Pakistan (GOP), 2009. Agriculture. Finance division. http://www.finance.gov.pk/survey_0910.html

Grindeland JM, Sletvold N and Ims RA, 2005. Effects of floral display size and plant density on pollinator visitation rate in a natural population of Digitalis purpurea. Funct. Ecol. 19:383-390.

Heinrich B, 1984.Strategies of Thermoregulation and Foraging in two Vespid Wasps, Dolichovespula maculata and Vespula vulgaris. J. Comp. Physiol. 154:175-180.

Hilário SD, Imperatriz-Fonseca VL and Kleinert AMP, 2000. Flight Activity and Colony Strength in the Stingless bee Melipona bicolor (Apidae, Meliponinae). Rev. Bras. Biol. 60:299-306.

Khan SU, Hassan M, Khan FK and Bari A, 2010. Climate classification of Pakistan. Balwois 2010 Conference, Ohrid, Republic of Macedonia. http://www.balwois.com/balwois/administration/f ull-pa per/ffp-1295.pdf: p. 1-47.
Klein AM, Vaissiere BE, Cane JH, Steffan-Dewenter I, Cunningham SA, Kremen $\mathrm{C}$ and Tscharntke T, 2007. Importance of pollinators in changing landscapes for world crops. Proc. R. Soc. Lond. B. 274:303-313.

Kunin WE, 1993. Sex and the single mustard: population density and pollinator behavior effects on seed-set. Ecology74: 2145-2160.

Lane KK and David RT, 2006. Environmental and genotypic effects on Russian-Hybrid and Italian Honey Bee (Apis mellifera) (Hymenoptera: Apidae) foraging behavior. Environ. Entomol. 35:1610-1616.

Meyerhoff G, 1954.Investigations on the effect of bee visits on rape. Arch Geflugelz Kleintierk 3:259306.

Moritz RF, Härtel S and Neumann P, 2005. Global invasions of the western honeybee (Apis mellifera) and the consequences for biodiversity. Ecoscience 12: 289-301.

Régnière JP, Bentz JB and Nealis V, 2012. Effects of temperature on development, survival and reproduction of insects: experimental design, data analysis and modeling. J. Insect. Physiol. 58: 634647.

Ricketts TH, 2004. Tropical forest fragments enhance pollinator activity in nearby coffee crops. Conser. Biol. 18: 1262-1271.

Saeed S, Malik SA, Dad K, Sajjad A and Ali M, 2012.In Search of the Best Native Pollinators for Bitter Gourd (Momordica charantia L.) Pollination in Multan, Pakistan. Pak. J. Zool. 44:1633-1641.

Sajjad A, Saeed S and Masood A, 2008. Pollinator Community of Onion (Allium cepa L.) and its Role in Crop Reproductive Success. Pak. J. Zool.40: 451-456.

Sánchez-Lafuente AM, Guitian J, Medrano M, Herrera CM, Rey PJ and Cerda X, 2005.Plant traits, environmental factors, and pollinator visitation in winter-flowering Helleborus foetidus (Ranunculaceae). Ann. Bot. 96: 845-852.

Savopoulou-Soultani M, Papadopoulos NT, Milonas P and Moyal P, 2012.Abiotic factors and insect abundance. Psyche 2012: 1-2.

Shivanna BK, Gangadhara B, Naik MK, Basavaraja R, Nagaraja CM, Kalleswara S and Karegowda C, 2011.Impact of abiotic factors on population dynamics of sucking pests in transgenic cotton ecosystem. Int. J. Nat. Sci. 2: 72-74. 


\section{Muhammad Aslam Farooqi et al.}

Sihag RC, 2018. Some unresolved issues of measuring the efficiency of pollinators: Experimentally testing and assessing the predictive power of different methods. Int. J. Ecol. Vol. 2018. $10.1155 / 2018 / 3904973$.

Singh J, Agrawal OP and Mishra RC, 2006. Foraging rates of different Apis species visiting parental lines of Brassica napus L. Zoos Print J. 21(4):2226-2227

Sorensen FC and Webber JE, 1997. On the relationship between pollen capture and seed set in conifers. Can. J. Forest Res, 27(1): 63-68.

Southwick EE and Moritz RFA, 1987. Effects of meteorological factors on defensive behavior of honey bees. Int. J. Biomet. 31: 259-265.

Stabentheiner A and Kovac H, 2014. Energetic optimisation of foraging honeybees: Flexible change of strategies in response to environmental challenges. PLoS One 9: e105432. doi:10.1371/journal.pone.0105432

Taylor LR, 1963. Analysis of the effect of temperature on insects in flight. J. Anim. Ecol. 32: 99-117.

Tirado RG, Simon G and Johnston P, 2013. Bees in decline: A review of factors that put pollinators and agriculture in Europe at risk. Greenpeace Research Laboratories Technical Report (Review). pp. 1-48. Greenpeace International, Ottho Heldringstraat 5, 1066 AZ Amsterdam, the Netherlands.

Tripath H, 2011. Beekeeping and agricultural productivity: Role of beekeeping with indigenous bee Apis cerana in crop production under the mango tree. Pp. 12-47.
Villalobos EM and Shelly TE, 1996.Temporal and Spatial variation in the foraging behavior of honey bees (Hymenoptera: Apidae) at Chinese Violets. Fla. Entomol. 79:398-407.

Wang H, Cao GX, Wang LL, Yang YP, Zhang ZQ and Duan YW, 2017. Evaluation of pollinator effectiveness based on pollen deposition and seed production in a gynodieocious alpine plant, Cyananthus delavayi. Ecol.Evol. 7:8156-8160.

Williams IH, Martin AP and White RP, 1986. The pollination requirements of oil-seed rape (Brassica napus L.). J Agric. Sci. 106:27-30.

Willmer PG, Cunnold H and Ballantyne G, 2017. Insights from measuring pollen deposition: quantifying the preeminence of bees as flower visitors and effective pollinators. Arthropod-Plant Inte. 11:411-425.

Zameer SU, Bilal M, Fazal MI and Sajjad A, 2017. Foraging behavior of pollinators leads to effective pollination in radish Raphanus sativus L. Asian. J. Agric. Biol. 5: 221-227.

\section{Contribution of Authors}

Farooqi MA: Supervision of the experiment and approval of the manuscript

Sajjad A: Conceptualization of the study, data analysis and manuscript writing Aslam MN \& Akram W: Data collection \& analysis and manuscript writing 